\title{
On the Relevance of the Concept of Intrinsic Evil: Francisco Suárez and Contemporary Catholic Virtue Ethics Approaches
}

\author{
Nenad Polgar
}

\begin{abstract}
The article explores the relevancy of the concept of intrinsic evil/intrinsically evil acts in contemporary Catholic theological ethics as a particular way of giving an account of (moral) evil. The argument proceeds in two steps. In the first step the author turns to Francisco Suarrez as one of the first theologians who tried to deal with the concept of intrinsic evil in an extensive and systematic way. The point of this historical exploration is to determine the meanings of this concept as it started to appear more frequently in the ethical discourse. In the next step the author presents two contemporary positions within Catholic theological ethics, those of Joseph Selling and Dana Dillon. Although both authors are proponents of virtue ethics, they disagree fundamentally on the role of the concept of intrinsic evil within this approach. While Joseph Selling argues in favour of eliminating this concept from theological ethics, Dana Dillon posits that theological ethics cannot function without it. In the rest of the article, the author explores this disagreement through various ways in which the concept can be used, while taking into account the aforementioned meanings of the concept. In the end, the author sides with Joseph Selling, since the concept of intrinsic evil does not seem to be able to fulfil the role it was assigned within Catholic theological ethics.
\end{abstract}

\section{Introduction}

Conceptualising evil within particular disciplines and traditions presupposes, but also influences, the development of methodological tools and concepts. The reliability of these tools and concepts depends on how well they are able to bridge the gap between fundamental insights of these disciplines/traditions and contemporary challenges related to giving an account of evil. Every tradition has developed such tools and concepts, but religious traditions are struggling today in their attempts to provide credible accounts of evil. Therefore, the public focus has shifted away from theological explanations towards other disciplines in search of more reliable accounts of evil. Understanding why this happened is the first step for religious traditions in regaining their credibility when it comes to giving an account of evil; not because there is a need to compete with other 
disciplines in this regard, but because valuable insights will be lost if religious traditions become irrelevant for this discourse.

When it comes to Catholic theological ethics a recent publication, entitled Reframing Catholic Theological Ethics by Joseph Selling, has suggested that the inability of this discipline to overcome an act-oriented approach to ethical thinking in favour of developing a credible ethical vision (which needs to give an account of moral evil), might depend on the willingness to eliminate the notion of intrinsic evil. ${ }^{1}$ On the other hand, a recently published article in Horizons, entitled Debating Intrinsic Evil by Dana Dillon, argued that such a goal-oriented approach, usually associated with virtue ethics, is unthinkable within the Catholic tradition without maintaining the concept of intrinsically evil acts. ${ }^{2}$

This article will, thus, explore the significance of the concept of intrinsic evil in a theological-ethical account of moral evil. By focusing on the historical roots of this concept, the article will try to draw out its meanings in order to, subsequently, pose the question whether the concept still contributes to the development of a credible account of moral evil and, consequently, to theological ethics. More precisely, the historical exploration of the concept of intrinsic evil will present the view of Francisco Suárez as one of the earliest theologians who discussed the problem of intrinsically evil acts explicitly, and somewhat systematically, within his novel theory of natural law. ${ }^{3}$ Having this range of possible meanings of the concept in mind, I will subsequently engage with the two authors mentioned earlier, Selling and Dillon, in order to try to discern the reasons behind the discrepancy in their evaluation of the importance of the concept of intrinsically evil acts.

\section{Intrinsic Evil in Francisco Suárez's Thought}

Considering Suárez's understanding of natural law and, especially, his static notion of human nature ${ }^{4}$, it is not surprising to discover that the concept of intrinsically evil acts has

1 See Joseph A. Selling, Reframing Catholic Theological Ethics (Oxford: Oxford University Press, 2016), p. 200.

2 See Dana L. Dillon, 'Debating Intrinsic Evil', Horizons 41:1 (2014), p. 130.

${ }^{3}$ Francisco Suárez was not the first theologian who used the term intrinsically evil acts. John Dedek's excellent studies identify Durand of Saint Pourçain as the theologian who coined it and give an overview of the development of the concept in theological discussions in $12^{\text {th }}$ and $13^{\text {th }}$ century. See John Dedek, 'Moral Absolutes in the Predecessors of St. Thomas', Theological Studies 38:4 (1977), pp. 654-680; Id., 'Intrinsically Evil Acts: An Historical Study of the Mind of St. Thomas', The Thomist 43:3 (1979), pp. 385-413; Id., 'Intrinsically Evil Acts: The Emergence of the Doctrine', Recherches de Théologie Ancienne et Médiévale 50 (1983), pp. 191-226. For a critique of Dedek's studies, especially their methodology, see Matthew R. McWhorter, 'Intrinsic Moral Evils in the Middle Ages: Augustine as a Source of the Theological Doctrine', Studies in Christian Ethics 29:4 (2016), pp. 409-423.

4 It is impossible to explain Suárez's notion of natural law and his view of human nature adequately here. For our purposes it will suffice to point out that in developing his understanding of natural law Suárez insists that it is immutable and universal both and in equal measure in its first principles and in its most concrete conclusions. In order to maintain this understanding, he sees the role of practical reason as simply deducing a conclusion from a relevant precept of the natural law in a given situation. Since these judgements presuppose only knowledge of human nature, more general 
a place, and a significant one, within his ethical theory. In that regard, Suárez goes beyond the affirmation of the idea that there are classes of acts that are always morally wrong to commit, and actually uses the term itself (actus intrinsece mali). ${ }^{5}$ The author engages in the most extensive treatment of the topic in disputation 7 of his work De bonitate et malitia humanorum actuum.

In his usual style, Suárez first presents and comments on two opposing positions on the topic and finally arrives at the third with which he agrees. This position confirms that there are acts that are always evil and in the continuation of the disputation 7 he specifies it further through a number of assertions and corollaries. The first assertion Suárez makes is 'that some acts of the will are in themselves and in their objects evil prior to any will prohibiting them; they are independent of that will with respect to the aspect of evil' 6 . He argues that the assertion is firmly supported by tradition (Augustine, Aquinas, Scotus, Durandus, Cajetan, etc.), although, he notes, these authors do not agree on which acts ought to be counted among those that are evil in themselves. Therefore, Suárez proceeds by giving some examples of acts that are always evil and on this list he puts hatred of God, acting against conscience, or right reason, or a precept of a superior, adultery, lying, willingness to deceive, and willingness not to keep a promise. ${ }^{7}$ The reason,

precepts of natural law, and relevant circumstances of a given situation, the truth of a conclusion is identified with the correctness of a syllogism. For a more detailed treatment of Suárez's understanding of natural law, see Francisco Suárez, 'De legibus ac Deo legislatore', Selections from Three Works, edited by Thomas Pink (Indianapolis, IN: Liberty Fund, 2015), pp. 151-355; Paul Pace, 'Suárez and the Natural Law', A Companion to Francisco Suárez, edited by Victor M. Salas and Robert L. Fastiggi (Leiden: Brill, 2015), pp. 274-296; James Gordley, 'Suárez and Natural Law', The Philosophy of Francisco Suárez, Benjamin Hill and Henrik Lagerlund (Oxford: Oxford University Press, 2012), pp. 209-229.

5 The term appears in his treatise De bonitate et malitia humanorum actuum (henceforth De bonitate) but also in De legibus ac Deo legislatore (henceforth De legibus). See Francisco Suárez, Opera omnia, vol. 4 (Paris: Vivès, 1856), tract. 3, disp. 7, sect. 1. n. 13, p. 375; Ibid., vol. 5, lib. 2, cap. 7, n. 5, p. 113. (For the English translation of De legibus I am relying on Thomas Pink's translation in his Selection from Three Works (see the previous footnote), but the references will be given always to the Vivès edition). From the fact that the term appears only once in the whole disputation, Servais Pinckaers concludes that it only began to become a part of theological discussions. See Servais Pinckaers, The Pinckaers Reader: Renewing Thomistic Moral Theology (Washington, D.C.: Catholic University of America Press, 2005), p. 219.

${ }^{6}$ Francisco Suárez, Opera omnia, vol. 4, tract. 3, disp. 7, sect. 1, n. 6, p. 373: 'Aliquos actus voluntatis ex se, et ex vi suorum obiectorum esse malos ante omnem voluntatem prohibentem et independenter ab illa quoad rationem malitiae.' (For English translation of De bonitate I am relying on Sydney Penner's translation, which can be found on his webpage: http://www.sydneypenner.ca/SuarTr.shtml, but the references will be given always to the Vivès edition).

7 See ibid., tract. 3, disp. 7, n. 7, p. 373. Similarly, in De legibus, when writing about the third-level precepts of natural law, Suárez writes: 'Other conclusions require more reflection, of a sort not easily within the capacity of all, as is the case with the inferences that fornication is intrinsically evil, that usury is unjust, that lying can never be justified, and the like.' Ibid., vol. 5, lib. 2, cap. 7, n. 5, p. 113: 'Aliae majori indigent discursu, et non facile omnibus notae, ut fornicationem esse intrinsece malam, usuram esse injustam, mendacium nunquam posse honestari, et similia.' It seems that in this quotation Suárez is using the term 'intrinsically evil' as a synonym for 'unjust', or 'can never be 
according to Suárez, why these acts are intrinsically evil consists in their objects and the fact that the will receives its goodness or malice from its object.

It is instructive to stop here for a moment and to consider the kinds of acts that Suárez puts on the list of intrinsically evil acts. Firstly, what is immediately evident is that the listed acts are certainly not specified in the same way or with the same or similar amount of detail. For instance, there is a big difference between specifying an act as 'acting against right reason' and 'adultery'. While the former is, technically, a formal description of every morally wrong act, the latter is a specific description of an act combining both formal and material elements. ${ }^{8}$

Secondly, Suárez's list also contains an act against a precept of a superior and willingness not to keep a promise. These are both kinds of acts that are problematic for the point Suárez wanted to demonstrate since he does not seem to consider them absolutely bad in all circumstances. In the case of the former, a precept of a superior ought to be followed unless the superior lapses into tyranny ${ }^{9}$, which shows that Suárez does not consider the act morally wrong in itself or in its object. ${ }^{10}$ In the case of the latter, he shifts the discussion and talks about God as someone who would never fail to uphold a given promise and this makes it unsuitable as an example of an intrinsically evil act, due to the change of the agent. ${ }^{11}$

Both of these cases then confirm that Suárez's notion of intrinsically evil acts certainly does not mean 'irrespective of the context, intention, and circumstances', as it is often understood today. The designation 'intrinsic' is then seemingly nothing but a reference to a judgement of right reason pronouncing ' $x$ is in conformity/disconformity with human nature' where $x$ is a concrete and contextualised act. ${ }^{12}$ In this sense, one could

justified'. One has to be careful then not to read in his text the specific meaning or meanings that the term 'intrinsic evil' acquired later on.

8 The prohibition against adultery is called a synthetic norm (do not commit adultery) in contemporary theological ethics, since it combines a moral judgement and a material description of the act.

9 See Francisco Suárez, Opera omnia, vol. 5, lib. 3, cap. 4, n. 6, p. 186.

10 Of course, Suárez might argue here that the object on an act against the will of a superior who lapsed into tyranny is not the object he writes about here (acting against a precept of a superior), but one cannot discern this from the way he formulated the object of an intrinsically evil act in this case. This means that either the act can be morally right in some circumstances or it is not a good example of an act intrinsically evil in its object. As will become evident later on, such imprecisions when it comes to defining objects of intrinsically evil acts is one of the main reasons why the concept became confusing and unclear.

11 See Francisco Suárez, Opera omnia, vol. 4, tract. 3, disp. 7, sect. 1, n. 7, p. 373. The reason why he shifts the discussion to God is to show that the malice of willingness not to keep a promise does not depend on (divine) will, but on the fact that this object is evil per se. This is a valid point, but the shift in context complicates its application to human affairs. Namely, there is a major difference between saying that God would never break a promise and that human beings should never break a promise, because the way God makes promises and the way human beings make promises differs substantially. So, either objects of these two acts ought to be specified differently or, less likely, the object here refers to the end of an act. Neither of these options, however, can demonstrate Suárez's point that there are some acts whose objects are intrinsically evil in a meaningful way.

12 See Terence Irwin, The Development of Ethics: A Historical and Critical Study: Volume II: From Suárez to Rousseau (Oxford: Oxford University Press, 2008), p. 40. 
exchange Suárez's term 'intrinsically evil act' with the term 'morally wrong act' without losing anything of its meaning. Alternatively, his concept of intrinsically evil acts could refer to acts that have been specified in detail in order to include all morally relevant elements, as in the case of adultery or acting against the precept of a superior, unless he lapses into tyranny (plus any other circumstance that might justify one in acting against a precept of a superior). Such a concept of intrinsically evil acts would not cause any problems in contemporary debates, but it would also be largely useless as a methodological tool.

\section{Nature of Intrinsically Evil Acts}

After asserting that there are intrinsically evil acts Suárez focuses in the third corollary on the nature of intrinsically evil acts. They are not such, he explains, because evil is somehow joined to or inherent in their physical entity, but because they have evil conjoined to them via their objects. Among such acts, Suárez differentiates between two kinds: (1) those that have evil conjoined to them 'by the force of a direct and physical tendency' and (2) those that are evil 'from an indirect tendency'13.

A number of interesting points are raised in this text. Firstly, there seems to be a certain contradiction between Suárez's explanation of the nature of intrinsically evil acts and his explanation of the first kind of intrinsically evil acts. In the former, Suárez categorically denies that acts could be intrinsically evil on the basis of their physical entity, but in the latter he explains the relation between acts and intrinsically evil objects in terms of a direct and physical tendency. At first glance, this might strike one as a contradiction, unless there is a way to distinguish between 'physical entity' and 'direct and physical tendency'. However, Suárez did not pursue this point further explicitly. What Suárez probably tried to express here is the idea that there are acts whose objects have inherent ends that are normative for these acts, and in relation to which any other end an agent might have in performing them is accidental and remote. ${ }^{14}$ Consequently, to perform such an act without respecting its inherent end would mean to engage in an intrinsically evil act. Leaving aside the issue of natural teleology for the moment, the fact that he calls this

13 Francisco Suárez, Opera omnia, vol. 4, tract. 3, disp. 7, sect. 1, n. 13, p. 375: 'Nam quidam habent adiunctam malitiam ex vi directae, et physicae tendentiae in obiectum, quod contingit quando vel obiectum habet omnino immutabilem conditionem illam ex qua oritur turpi tudo, ut est in odio Dei, aut quando in ipso obiecto directe volito proponitur illa conditio, ex qua oritur illa turpitudo, ut est in voluntate mentiendi, furandi [...].Aliquando vero non adiungitur malitia ex vi directae vel physicae tendentiae, sed tantum ex indirecta: ut cum aliquis vult hanc rem accipere, vel ad hanc mulierem accedere, et in obiecto volito non ponit conditionem non suae, vel alienae.'

14 See Pinckaers, The Pinckaers Reader, p. 222. Pinckaers argues further: 'Without doubt, Suárez had not yet established a connection between this difference of ends and the distinction between finis operis and finis operantis, but the idea is clearly expressed and will at once be taken up. We should note that although certain texts of St. Thomas could lend themselves to Suárez's distinction, St. Thomas in no way gave them such a meaning, to the detriment of finality, in his analysis of the moral act.' Ibid. Perhaps the first theologian who explicitly formulated this idea is Durand of Saint Pourçain. He argued that God cannot dispense from those precepts whose matter (a materia talium praeceptorum) is inseparable from the ratio debiti. See Dedek, 'Intrinsically Evil Acts: The Emergence', p. 221. 
tendency of objects towards evil direct and physical, is a very unfortunate decision that might easily, as it did, turn into designating some physical acts ${ }^{15}$ as intrinsically evil.

An interesting case in this context is the seventh commandment that prohibits lying. Suárez defines lying as 'the disaccord between the words and the mind'16; that is, as what I called a physical act. Furthermore, lying is certainly one of his paradigmatic examples of intrinsically evil acts. However, if intrinsically evil acts, as Suárez claims, do not refer to acts whose evil is somehow joined to or inherent in their physical entity, then how can he possibly claim that 'the disaccord between the words and the mind' is an example of an intrinsically evil act? In other words, his example either does not meet his own definition of what can or cannot qualify as an intrinsically evil act, or his notion of the 'physical entity (of an act)' means something entirely different.

Secondly, this relation between objects and their inherent ends is not a new idea; a number of Scholastic writers speculated about it in the context of divine dispensations, i.e. whether God can re-direct, as it were, material acts (that are directed to evil inherent ends) so that they do not tend towards evil anymore, but towards God or the final end. In relation to that, Scotus posed the crucial question regarding these acts/objects by asking whether there are some acts that can never be re-directed from their 'inherent end'. His reply, based on his understanding of the natural law in the strict sense, was modest since it included only one act on the list of such acts - hatred of God. ${ }^{17}$ Suárez, on the other hand, recognises the uniqueness of this act ${ }^{18}$, but enlarges the list significantly.

Thirdly, Suárez claims that acts of his second category of intrinsically evil acts tend only indirectly towards intrinsically evil objects. Therefore, he argues, they can become morally good, if the conditions in the object were to change. It is clear from this that Suárez is applying here his theory on the possibility of change in the subject matter of an object to which a precept of natural law is applied so that a given precept would not apply anymore,

15 Although it is impossible to discern with absolute certainty what Suárez means by 'physical entity' of an act, what I mean by 'physical act' is its material aspect that corresponds to the question 'what is done or omitted (materially)'; for instance, a sexual act, telling a falsehood, waving a hand, breaking a promise, remaining silent, cutting (someone) with a knife, giving money (to someone), etc. All of these examples can be specified to a lesser or higher degree and they already have some kind of reference to an agent who performs them, but this reference is not sufficiently specified so that a moral judgement could be made.

${ }^{16}$ Francisco Suárez, Opera omnia, vol. 5, lib. 2, cap. 15, n. 23, p. 152.

17 See Allan B. Wolter and William A. Frank, Duns Scotus: On the Will and Morality (Washington, D.C.: The Catholic University of America Press, 1997), pp. 57-64. Scotus reaches this conclusion because, for him, hatred of God is the only act in which generic (object-based) and specific (circumstantial) goodness merge, since there is no logical possibility to claim that an act of hatred of God could be directed to a good end.

18 Suárez recognises the uniqueness of the act of hatred of God, but he relates it to the issue of ignorance/knowledge of what one is doing: 'If the evil is so obvious that one cannot be ignorant of it, as is perhaps with the hatred of God, that act could not be a human act without being evil. Perhaps it is for that reason that Scotus said that this act is especially intrinsically evil.' Francisco Suárez, Opera omnia, vol. 4, tract. 3, disp. 7, sect. 1, n. 13, p. 375: 'Si tamen tam patens sit malitia, ut non possit ignorari, ut fortasse est in odio Dei, non poterit ille actus esse humanus, quin sit malus; et ideo forte Scotus dixit hunc actum esse specialiter intrinsece malum.' 
which means that the natural law is preserved in its immutability. ${ }^{19}$ However, if one were to compare Suárez and Aquinas on this point, one would notice that Suárez considers as intrinsically evil not only those acts that have an intrinsic deformity (Aquinas calls these acts malum secundum se) ${ }^{20}$, but also acts whose deformity is such that it could disappear if object-forming circumstances change.

In summary, one can clearly see the early stage of the development of the concept of intrinsically evil acts in Suárez's account. Unfortunately, already at this stage of its development, the concept seemed to have suffered from a number of inconsistencies that threatened it to such an extent that it might become completely incoherent and useless.. In effect, Suárez claims that the category of intrinsically evil acts spans from those acts that tend directly and physically towards intrinsically evil objects, through those whose objects are deformed (but could change), and all the way to acts that are intrinsically evil because they are instances of acting against right reason. Between these he also inserts acts such as adultery and breaking a promise and all of this shows, in my opinion, that it is almost impossible to discern what the defining characteristics of intrinsically evil acts are, except the fact that they are instances of acts against right reason, i.e. they are morally wrong. If this is so, then Suárez's engagement with the concept of intrinsically evil acts seems to be largely an attempt to strengthen the notion of objective morality amidst the theological struggle between essentialism and voluntarism and he does so by using a concept that he believes to be based firmly in the tradition.

That this problem of conceptual confusion about the term intrinsically evil acts has only become more acute in later times is evident when one fast-forwards from Suárez's time through the manualist tradition to contemporary times. In recent years, theologians who have worked on this term, managed to isolate an astonishing number of its meanings. For instance, in his taxonomy of views on the concept of intrinsic evil, James Bretzke identified five different meanings of the term ${ }^{21}$, while Werner Wolbert lists nine possible meanings. ${ }^{22}$

Nevertheless, one could rightly claim that the concept of intrinsic evil has never been defended more strongly in Catholic theological ethics than in the second half of the twentieth century. During the last century the concept of intrinsic evil has started to appear more and more often in those documents of the teaching office of the Catholic Church that deal with some aspects of sexual ethics. Finally, the term itself was incorporated in the encyclical letter Veritatis splendor, where it was argued that 'in teaching the existence of intrinsically evil acts, the Church accepts the teaching of Sacred Scripture' ${ }^{23}$ This usage of

${ }^{19}$ For instance, in the case of the Old Testament prophet Hosea, Suárez argues, the precept against fornication has not been abolished, because 'God has power to transfer to a man dominium over a woman without her consent' which makes the intercourse not an act of fornication but a marital act. See ibid., vol. 5, lib. 2, cap. 15, n. 20, p. 149.

20 See Thomae Aquinatis, Quaestiones Quodlibetales, edited by Raymundi Spiazzi (Turin: Marietti, 1956), quod. 9, q. 7, a. 2.

21 See James Bretzke, 'Debating Intrinsic Evil', Horizons 41:1 (2014), pp. 128-129.

22 Werner Wolbert, 'Tendencies in Catholic Moral Theology as Reflected in Veritatis Splendor', Freiburger Zeitschrift für Philosophie und Theologie 47:1-2 (2000), pp. 241-244.

23 John Paul II, Veritatis splendor, online at http://w2.vatican.va/content/john-paulii/en/encyclicals/ documents/hf_jp-ii_enc_06081993_veritatis-splendor.html (accessed 2018-04-24), n. 81. Earlier documents referred to the concept of intrinsic evil by other names. For instance, Casti 
the concept in Veritatis splendor seem to have been inspired largely by similar motives that guided Francisco Suárez a few centuries ago. Namely, in both cases the concept served to ground claims of objectivity of particular moral judgements, while reinforcing it further by appeals to the tradition in order to combat extreme essentialist and voluntarist tendencies in theology (Suárez) or the perceived threat of moral relativism and proportionalists' vision of renewing theological ethics (Veritatis splendor). ${ }^{24}$

With this in mind, I will turn now to the two contemporary approaches to virtue ethics of which one shares concerns and supports efforts of Veritatis splendor and traditionalists (Dana Dillon), while the other finds them misguided (Joseph Selling).

\section{Intrinsic Evil and Virtue Ethics: Two Approaches}

Both Joseph Selling and Dana Dillon argue in favour of accepting goal-oriented virtue ethics as the main approach of Catholic theological ethics. Interestingly enough, the authors also agree that act analysis ought to complement virtue ethics, i.e. that virtue ethics in itself, is not enough for a comprehensive approach to ethics, since issues related to behaviour, to what is right and what is wrong, are also pertinent and need to be reflected on and answered. ${ }^{25}$ However, the two authors disagree on the role of the concept of intrinsically evil acts within this the act analysis part of the comprehensive approach to ethics.

For Selling, it is precisely the continuous adherence to this and similar concepts within the official moral doctrine of the teaching office of the Catholic Church and within theological ethics in general, that hinders the renewal of the discipline along the lines of the goal-oriented approach. Furthermore, Selling argues that one of the essential tasks roles of the concept of intrinsic evil - identification of morally wrong acts - can just as easily be

Connubii (1930) uses 'intrinsically contrary to nature' (n. 54), 'intrinsically dishonest (or vicious)' (n. 54), and 'evil in its intrinsic nature' (n. 61); Humanae vitae (1968) follows it by using the term 'intrinsically dishonest' (n. 14); Persona humana (1975) employs 'intrinsically disordered' (n. 8); Reconciliatio et paenitentia (1984) uses 'intrinsically grave' (n. 17) and 'intrinsically illicit' (n. 18); finally, Veritatis splendor (1993) opts for 'intrinsically evil' (n. 80). As one can see, these variations on the theme could be a topic of research in themselves, because it is far from clear that the exact same idea is expressed by them.

${ }^{24}$ John Paul II was certainly not an isolated voice in promoting the usage of the concept of intrinsic evil in contemporary theological ethics. In fact many have argued that in Veritatis splendor he championed the cause of the so-called traditionalist school (especially the New Natural Law theorists), who, similarly to the so-called revisionists, were engaged in the project of renewing theological ethics, but without challenging any normative judgements that the teaching office of the Catholic Church might have reached. Expectedly, they reacted favourably to the promulgation of Veritatis splendor. See Germain Grisez, 'Revelation versus Dissent', Considering Veritatis Splendor, edited by John Wilkins (Clevelend, OH: The Pilgrim Press, 1994), pp. 1-8; Martin Rhonheimer, 'Intrinsically Evil Acts and the Moral Viewpoint: Clarifying a Central Teaching of Veritatis splendor', Veritatis Splendor and the Renewal of Moral Theology, edited by Joseph A. DiNoia and Romanus Cessario (Princeton, NJ: Scepter Publishers, 1999), pp. 161-193.

25 See Selling, Reframing Catholic Theological Ethics, pp. 7-12; Dillon, 'Debating Intrinsic Evil', pp. 130131. 
fulfilled by classifying some kinds of acts as inappropriate for living virtuously. ${ }^{26}$ For Dillon, on the other hand, 'virtue ethics ultimately does not work as an authentic way of handing on the Catholic moral tradition unless it includes an affirmation of the concept of intrinsically evil acts' 27 .

Recalling the range of possible meanings of the term intrinsically evil acts already present in Suárez's writings, the most pertinent question is what the two authors have in mind when taking a position for or against the usage of this concept in contemporary theological ethics. In this sense, Selling refers to the widespread understanding of intrinsically evil acts as those acts that are supposed to be morally wrong on the basis of their object, regardless of any (further) intention or circumstances. However, the problem with this understanding, he continues, is that it is never entirely clear how the object of an act was specified, i.e. whether it refers to a physical act, circumstantiated physical act, circumstantiated physical act with some notion of intention, or something else. ${ }^{28}$ In other words, it is not clear, as we already saw in Suárez, whether the specification of the object is trying to describe an act or already pronounce a moral judgement on it. ${ }^{29}$ This being so, the usage of the concept obfuscates the underlying moral methodology and hinders, according to Selling, 'our ability to have a coherent ethical conversation' ${ }^{30}$. Since the renewal of theological ethics depends also on this ability, Selling's reason for excluding the concept of intrinsically evil acts from theological ethics is clear.

Dillon, on the other hand, seems to reject any understanding of intrinsically evil acts as physical acts and defines them as 'types of acts that, by their nature, cannot be ordered to ends compatible with the Christian life'31. In order to explain what this 'nature' of types of acts is, Dillon refers to Aquinas and uses his notion of 'the substance of the act', which, she claims, consists of what the agent did and why he/she did it, including the circumstances without which these two cannot be understood. ${ }^{32}$ Thus, for her, examples of

26 See Selling, Reframing Catholic Theological Ethics, pp. 200.

27 Dillon, 'Debating Intrinsic Evil', p. 130.

28 See Selling, Reframing Catholic Theological Ethics, pp. 20-22.

29 This distinction between describing and evaluating is important since it clarifies what is meant by a specific usage of the concept of intrinsic evil. However, while acknowledging this distinction, one should also keep in mind that description and evaluation are not simply successive acts of moral analysis. Instead, describing an act in the context of a moral analysis - for instance, to kill a person already picks out those elements of an event that have a potentially evaluative significance and eliminates others as irrelevant (for instance, that a person was tall or short). Hence, when describing an act in the context of a moral analysis, one has already begun (but not completed!) the process of morally evaluating it.

$30 \mathrm{Ibid}, 21$.

${ }^{31}$ Dillon, 'Debating Intrinsic Evil', p. 137.

32 See ibid, p. 134. Dillon refers to four articles of Aquinas' Summa theologiae I-II, q. 7, from which, she claims, her notion of 'the substance of the act' is derived. However, the text of article 4 of this question refutes her claim that the substance of the act consists of what the agent did and why he/she did it: 'Now, the motive and object of the will is the end. Therefore that circumstance is the most important of all which touches the act on the part of the end, viz. the circumstance 'why': and the second in importance, is that which touches the very substance of the act, viz. the circumstance 'what he did'.' Thomas Aquinas, 'Summa theologiae I-II', edited by Joseph Kenny, online at http://dhspriory.org/thomas (accessed 2017-11-05), q. 7, a. 4, resp. This text differentiates between what is the most important in the act (i.e. 'why') and the very substance of the act (i.e. 'what'), which 
intrinsically evil acts are adultery, murder, apostasy, and the types of acts enumerated in Gaudium et spes 27.33 Interestingly enough, Dillon laments the fact that sexual sins, described in overly physicalist terms, have been associated often with intrinsically evil acts, but she does not explicitly say whether she considers such acts intrinsically evil or not.

\section{A Critique of the Usage of the Concept of Intrinsic Evil}

When the positions of the two authors are compared and their divergent understandings of the concept of intrinsic evil are taken into account, their opposing positions on the importance of the concept of intrinsic evil within Catholic theological ethics might lose some of their edge. Namely, one cannot imagine that Selling would argue in favour of moral re-evaluation of adultery, murder, or apostasy as a part of his suggestion to dispose of the notion of intrinsically evil acts. Furthermore, it is unclear why Dillon would insist on keeping the notion of intrinsically evil acts, if these can just as well be classified as morally inappropriate acts within a Christian community. However, a clearer picture of both the two authors' understanding of the concept of intrinsic evil and its (ir)relevancy for theological ethics, might emerge through a further analysis of their positions.

This analysis will proceed by specifying three ways in which the notion of intrinsic evil can be used and looking at the two authors' positions through the lens of this categorization: 1) As a methodological tool, 2) as a result of an ethical analysis, and/or 3) as a pedagogical tool.

\section{Intrinsic Evil as a Methodological Tool}

By referring to the notion of intrinsic evil as a methodological tool I am raising the question whether this notion has a place in normative analyses of acts within theological ethics. Such analyses presuppose the development and usage of conceptual tools that help us identify and engage with potentially morally relevant elements of an act or a class of acts for the purpose of reaching an ethical judgement. The pertinent question in this regard is whether the concept of intrinsic evil performs a similar or equivalent function as concepts such as circumstances, end (intention), object, principle, rule, criterion, context, material norm, etc.

On this issue, Selling warns about the danger the notion of intrinsic evil represents insofar as it hinders meaningful ethical discussion, while Dillon seems, at least implicitly, to favour this usage. More precisely, Dillon rejects the objection against the concept of intrinsically evil acts which insists on 'the suggestion that what the agent intends can change the meaning and identity of the act ${ }^{\prime 34}$. If this objection is not valid, as she seems to think, then the concept of intrinsically evil acts can be used as a methodological tool that replaces the careful consideration of intention in the ethical analysis of an act. However, in this she is contradicting herself (since she claimed earlier that intention, 'the why', is part

seems to suggest that the 'why' is not a part of the substance of the act. However, in case there is any doubt left, Aquinas continues further down: 'Although the end is not part of the substance of the act, yet it is the most important cause of the act, inasmuch as it moves the agent to act [emphasis added].' Ibid., q. 7, a. 4, ad. 2.

33 See Dillon, 'Debating Intrinsic Evil', pp. 134-137.

34 See ibid., p. 135. 
of the substance of an act) and taking a position opposed to Aquinas, for whom the specification of a human action begins with the consideration of the end. ${ }^{35}$

The main problem and the reason why the two authors disagree on this point is because the term intention can signify two different things. Firstly, it can signify the intention towards the end and in that sense one has to know what the intention is in order to specify an act or a class of acts. ${ }^{36}$ Secondly, the intention can refer to a personal reason (motive) one has for performing an already specified act; what Suárez and the manualist called finis operantis. ${ }^{37}$ When it comes to this latter meaning of the term intention, I think Dillon is right in claiming that the intention cannot change the identity of the act, but this is only so if we assume that the identity of the act is already known. Selling, on the other hand, is concerned that assumptions of this kind are not very helpful for ethical analysis as they are imprecise and too wide in scope. Thus, they risk lumping together all killings as murders and all takings of what belongs to others as thefts.

Does this amount to both authors being right, once the necessary distinctions have been introduced? The answer to this question depends on where the boundaries of normative analyses of acts in theological ethics ought to be drawn. For Selling the normative analysis of acts concerns their identity and classification; the reasons why an act is (not) classified as intrinsically evil/inappropriate. Hence, for him, the concept of intrinsic evil has no place at this level of ethical deliberation. Dillon, on the other hand, does not seem to be interested in the reasons why certain acts are identified as intrinsically evil, but rather focuses on the fact that they are intrinsically evil and cannot be re-described. In other words, she glosses over this more fundamental level of ethical deliberation and engages with the analysis of acts once their moral objects have already been specified. Since most theologians would identify this kind of analysis with the work of a confessor, not an ethicist engaged in normative analysis of human acts, her usage of the concept of intrinsic evil does not fit into this first category of using the concept as a methodological tool.

Bearing that in mind, it still might be worthwhile to ask exactly how would the usage of the concept of intrinsically evil acts as a methodological tool look like in Dillon's approach. The answer to this question depends on whether her notion of intrinsically evil acts is closer to acts examples of murder and adultery, on the one hand, or speaking a falsehood and masturbation, on the other. In other words, the question is whether what qualifies as murder and adultery, on the one hand, or speaking a falsehood and masturbation, on the other, is something that can never be re-described by taking into account the intention of the agent.

As I pointed out earlier, one of the problems with the notion of intrinsically evil acts is that one can never be entirely sure what kinds of acts (in terms of the level and manner of specification) this concept incorporates, i.e. what does it mean to establish that an act is intrinsically evil. Furthermore, Dillon's argument that intrinsically evil acts have been specified within the Catholic tradition in such a way as to allow for some consideration of the agent is also not very helpful., Although such a consideration favours

\footnotetext{
35 See Thomas Aquinas, 'Summa theologiae I-II', q. 1., a. 3.

36 Example: Taking something that belongs to another (what is done) in order to feed the starving family (intention). Without knowing the latter, we can only wonder what the former amounts to or, worse, assume it is an act of theft.

37 Example: Committing a theft in order to buy a present for a dear friend.
} 
the former kind of description of acts (murder and adultery) in the contemporary perspective, there are plenty of voices within the Catholic tradition that would have no issue with categorising speaking a falsehood or masturbation as moral objects, i.e. as taking into account the relevant intention of the agent.

Due to its ambiguity, the task of specifying what the concept of intrinsic evil means, rightly understood ${ }^{38}$, seems extremely difficult to achieve. Since this severely affects its ability take on the role of a methodological tool, most contemporary theological ethicists opt for alternative concepts in their analysis of human acts.

\section{Intrinsic Evil as a Result of an Ethical Analysis}

The usage of the notion of intrinsic evil as a result of an ethical analysis explores its viability as a way of expressing ethical judgements on particular acts or classes of acts. This usage of the concept of intrinsic evil is very much associated with the fontes moralitatis approach of the late manualists. If the concept of intrinsic evil is used in this sense, its role in ethical discourse would be comparable to concepts such as moral object, synthetic norm, duty, nature, and law, if these are understood as imposing a clear ethical demand.

As I noted earlier, the two authors prefer to use different notions when it comes to expressing ethical judgements (intrinsically evil acts for Dillon, inappropriate or disproportionate acts for Selling). The reason why the authors prefer to use different terms here consists in the role the concept of intrinsically evil acts ought to play in a community. Dillon emphasises that this concept is pivotal in a community's striving for a shared sense of the ends and purposes of life and for avoiding the conclusion or attitude that how such ends and purposes are pursued ultimately depends on either individual choice or on the particular situation in which an agent finds himself/herself. ${ }^{39}$ Selling, on the other hand, emphasises that this process of communal discernment of shared goods and purposes is never completed and that the description/evaluation of acts is of secondary importance for it and necessarily shares the provisional character of the whole process of ethical discernment. ${ }^{40}$ These are both important concerns that show vividly why the authors prefer different terms. However, I argue that while the usage of the term inappropriate acts does not deny the first concern, the usage of the term intrinsically evil acts, in Dillon's usage and in the tradition to which she appeals, cannot adequately take into consideration the second concern.

This inadequacy is perhaps one of the main reasons why the concept of intrinsic evil acquired so many different meanings (as seen in Suárez's thought) and why using it as a way of expressing ethical judgements, in my opinion, turns too easily to authoritative pronouncements as a way of settling ethical disputes. This turn to authoritative pronouncements might be explained by the fact that even within the Catholic tradition and community there is often a plurality of views on what a certain object/act is/means and how it should be evaluated. In such a situation, the turn to authoritative pronouncements leaves the impression of certainty of an ethical judgement, but only by skipping necessary steps of the process of reaching that judgement and by imposing definitions of objects of acts 'from above'.

38 See Dillon, 'Debating Intrinsic Evil', p. 137.

39 See Dillon, 'Debating Intrinsic Evil', p. 139.

40 See Selling, Reframing Catholic Theological Ethics, pp. 21-22. 
Intrinsic Evil as a Pedagogical Tool

Finally, using the notion of intrinsic evil as a pedagogical tool refers to its viability as a means of teaching an individual or a community about moral right and wrong, by using examples of classes of acts, and about moral good and bad, insofar as one can point out values that these classes of acts are endangering. In this sense, the notion of intrinsic evil, i.e. the examples of intrinsically evil acts, would serve as a sort of 'danger' sign for an individual or a community.

Both authors seem to recognise the importance of some sort of concept that would perform this role of a 'danger' sign for an individual or a community, insofar as they acknowledge the process of moral development. Hence, one cannot talk to children about moral methodology, nor can one expect the majority of people to be versed in nuances of normative act analysis. Dillon makes this point by insisting that the necessary condition of a community's ability to form virtuous characters is precisely its ability to first teach its members about intrinsically evil acts. Failing to meet this condition, she argues, would disintegrate a community's shared sense of what would constitute a virtuous character, as well as ends and purposes of virtuous life. This, in turn, precludes not only meaningful discussions on morality within a community, but ultimately leads to its inability to sustain itself as a community. ${ }^{41}$

At first glance, Dillon's argument might strike one as disturbing insofar as it seems to claim that a community's ability to sustain itself depends on teaching its members about intrinsically evil acts. However, there is nothing particularly radical about it, provided one keeps in mind its pedagogical context. Given this context, the argument merely points out a truism that a community cannot hope to sustain itself through generations if it does not devise ways for how to teach its members about its identity and its values, starting from the most basic notions of what one ought to do and what to avoid doing.

There are, nevertheless, two issues about Dillon's argument that, I think, Selling would raise. The first concerns using the notion of intrinsic evil in this context, as opposed to calling these acts inappropriate or simply morally wrong. In other words, does the notion of intrinsic evil ${ }^{42}$, as Dillon understands it, add anything to a community's pedagogical function that might be missed by using these alternative notions? Of course, this argument can work both ways. Hence, if nothing is lost by ditching the notion of intrinsic evil, Dillon could argue, there is also nothing to be gained by using a different term.

The crucial difference between using the term intrinsic evil or one of the alternative terms in the pedagogical context emerges only when one takes into account the two other ways in which the notion of intrinsic evil can be used (as a methodological tool and as a result of an ethical analysis). Although these three ways of using the notion can be distinguished, they are nevertheless interrelated. Because of this, it does make a difference which notion is employed in the pedagogical context, since one would expect it to also have an impact on the Church's approach to, and vision of, ethical discourse in general. Since the notion of intrinsic evil has a tendency to absolutize the moral judgements that it

41 See Dillon, 'Debating Intrinsic Evil', p. 140.

42 'Rightly understood, intrinsically evil acts name types of acts that, by their nature, cannot be ordered to ends compatible with the Christian life.' Ibid., p. 137. 
expresses and to simplify the ethical discourse by insisting on the certainty of these judgements, it creates the wrong impression on how these judgements are reached. Consequently, Selling argues, the idea that morality is simply about following commandments and rules (what one ought to do or avoid) proceeds logically from this approach while the consideration of what one is trying achieve in the first place (ends and goals of moral life) becomes secondary or unimportant. ${ }^{43}$ Perhaps the most vivid proof of this is the fact that there was next to no discussion of virtuous living in theological ethics for centuries between the Council of Trent and the Second Vatican Council. ${ }^{44}$

On the other hand, an approach such as Selling's would benefit from an explanation of how members of a community could be taught about inappropriate or disproportionate acts. Since he argues that their categorisation as inappropriate or disproportionate acts shares the provisional character of the whole process of ethical discernment, this understanding should somehow be reflected also in how one learns about such acts. Apart from the fact that this necessitates a re-thinking of the Church's pedagogical tasks, it also raises the question whether the provisional character of this categorisation can adequately express the seriousness of a concrete ethical obligation.

\section{Conclusion}

There is no doubt that the emergence and usage of the concept of intrinsic evil ought to be viewed as an attempt to give an account of (moral) evil within a particular religious tradition and its discipline of theological ethics. Since its beginning and up until the second part of the twentieth century, this discipline has been, as James Keenan argues, 'nearly exclusively concerned with sins, that is, with particular actions determined to be wrong'. ${ }^{5}$ To this one should add the conceptual confusion surrounding this term, which is present already in the thought of Francisco Suárez, as well as the context of the struggle between essentialism and voluntarism in which it was coined, in order to get the sense of heavy theological baggage that this term is burdened with. Consequently, continuous insistence on this term risks being overwhelmed by this baggage or using the term in a simplistic way. This being so, one starts to wonder whether one of its essential roles, the affirmation of objective morality, could not be served better by an alternative theological term.

These insights can be perhaps fully appreciated only within a more adequate theological view of morality 'as a response to the Spirit's movements in our lives'46, or what is today known as a goal-oriented (Selling) or virtue ethics (Dillon) approach. As Dillon rightly notices, the widespread acceptance of virtue ethics within Catholic theological ethics does not negate the need for a serious reflection on human acts and behaviour. However, the results of this reflection cannot be simply taken over from tradition as if the

43 See Selling, Reframing Catholic Theological Ethics, pp. 199-200.

44 See ibid., pp. 84-119.

45 James F. Keenan, 'History, Roots, and Innovations: A Response to the Engaging Protestants', Ecumenical Ventures in Ethics: Protestants Engage Pope John Paul II's Moral Encyclicals, edited by Reinhard Hütter and Theodor Dieter (Grand Rapids, MI: William B. Eerdmans Publishing Company, 1998), p. 266.

46 Ibid. 
only point of using a method in theological ethics is to find a better way to ground conclusions that have already been reached.

One of the signs of such uncritical treatment of results of previous reflections is the usage of the concept of intrinsic evil, as I tried to show through the three ways in which the concept can be used. Perhaps the most important insight that came out of this analysis is that these three ways of using the concept cannot be separated from each other, which adds to the confusion about what an author who uses it is trying to express. This, in turn, risks arguing for, holding, and teaching, unexamined views whose persistence depends on the evocative force of the concept of intrinsically evil acts, but that cannot withstand a closer scrutiny. As a way of giving an account of evil, such an approach draws out the boundaries of moral evil in an inadequate way. Hence, relying on it does not only threaten the credibility of the discipline and tradition from which it speaks, but acts as a hindrance to genuine ethical analysis.

Nenad Polgar, University of Vienna nenad.polgar@univie.ac.at

\section{Bibliography}

Aquinas, Thomas, Quaestiones Quodlibetales. Edited by Raymundi Spiazzi. Turin: Marietti, 1956.

Aquinas, Thomas. 'Summa theologiae I-II'. Edited by Joseph Kenny. Online at http:/ / dhspriory .org/thomas (accessed 2017-11-05).

Bretzke, James. 'Debating Intrinsic Evil'. Horizons 41:1 (2014), pp. 116-129.

Dedek, John. "Moral Absolutes in the Predecessors of St. Thomas'. Theological Studies 38:4 (1977), pp. 654-680.

Dedek, John. 'Intrinsically Evil Acts: An Historical Study of the Mind of St. Thomas'. The Thomist 43:3 (1979), pp. 385-413.

Dedek, John. 'Intrinsically Evil Acts: The Emergence of the Doctrine'. Recherches de Théologie Ancienne et Médiévale 50 (1983), pp. 191-226.

Dillon, Dana L. 'Debating Intrinsic Evil'. Horizons 41:1 (2014), pp. 130-142.

Gordley, James. 'Suárez and Natural Law', in The Philosophy of Francisco Suárez, Benjamin Hill and Henrik Lagerlund. Oxford: Oxford University Press, 2012, pp. 209-229.

Grisez, Germain. 'Revelation versus Dissent', in Considering Veritatis Splendor, edited by John Wilkins. Clevelend, OH: The Pilgrim Press, 1994, pp. 1-8.

Irwin, Terence. The Development of Ethics: A Historical and Critical Study: Volume II: From Suárez to Rousseau. Oxford: Oxford University Press, 2008.

John Paul II. Veritatis splendor. Online at http://w2.vatican.va/content/john-paulii/en/encyclicals/ documents/hf_jp-ii_enc_06081993_veritatis-splendor.html (accessed 2018-04-24).

Keenan, James F. 'History, Roots, and Innovations: A Response to the Engaging Protestants', in Ecumenical Ventures in Ethics: Protestants Engage Pope John Paul II's Moral Encyclicals, edited by Reinhard Hütter and Theodor Dieter. Grand Rapids, MI: William B. Eerdmans Publishing Company, 1998, pp. 262-288. 
De Ethica. A Journal of Philosophical, Theological and Applied Ethics Vol. 5:1 (2018)

McWhorter, Matthew R. 'Intrinsic Moral Evils in the Middle Ages: Augustine as a Source of the Theological Doctrine'. Studies in Christian Ethics 29:4 (2016), pp. 409-423.

Pace, Paul. 'Suárez and the Natural Law', in A Companion to Francisco Suárez, edited by Victor M. Salas and Robert L. Fastiggi. Leiden: Brill, 2015, pp. 274-296.

Pinckaers, Servais. The Pinckaers Reader: Renewing Thomistic Moral Theology. Washington, D.C.: Catholic University of America Press, 2005.

Rhonheimer, Martin. 'Intrinsically Evil Acts and the Moral Viewpoint: Clarifying a Central Teaching of Veritatis splendor', in Veritatis Splendor and the Renewal of Moral Theology, edited by Joseph A. DiNoia and Romanus Cessario (Princeton, NJ: Scepter Publishers, 1999), pp. 161-193.

Selling, Joseph A. Reframing Catholic Theological Ethics. Oxford: Oxford University Press, 2016.

Suárez, Francisco. Opera omnia. vol. 4-5. Paris: Vivès, 1856.

Suárez, Francisco. 'De legibus ac Deo legislatore', in Selections from Three Works, edited by Thomas Pink. Indianapolis, IN: Liberty Fund, 2015, pp. 5-752.

Wolbert, Werner. 'Tendencies in Catholic Moral Theology as Reflected in Veritatis Splendor'. Freiburger Zeitschrift für Philosophie und Theologie 47:1-2 (2000), pp. 220-245.

Wolter, Allan B. and William A. Frank. Duns Scotus: On the Will and Morality. Washington, D.C.: The Catholic University of America Press, 1997. 